\title{
PENGENALAN TULISAN TANGAN SECARA ONLINE DENGAN MENGGUNAKAN METODE DOMINANT POINT DALAM SUATU BENTUK
}

\author{
Budiya Surya Putra, S.Kom. ${ }^{*}$ \\ Eva Haryanty, S.Kom.*
}

\begin{abstract}
ABSTRAK
Dengan perkembangan digital tablets dan microcomputers, pengenalan tulisan tangan secara online telah menjadi suatu topik yang sangat terkenal dalam dunia penelitian sejak tahun 1960-an. Satu alasan mengapa topik ini sangat terkenal adalah bahwa pengenalan tulisan tangan secara online menjanjikan kemudahan dalam memasukkan suatu dara ke dalam komputer dengan cara yang lebih dinamis, yaitu dengan cara menggunakan stylus pen bukan hanya sekedar menggunakan keyboard seperti yang kita lakukan selama ini.

Penelitian ini bertujuan untuk mempelajari teknik pengenalan tulisan tangan menggunakan metode dominant points, dan mengetahui seberapa baiknya komputer dalam mengenali suatu tulisan tangan dari user.

Dengan menggunakan pendekatan elastic matching, sistem ini dapat mentoleransi variasi lokal dan bentuk yang rusak seperti polayang melebar dan garis yang keluar dari bentuknya. Dari uji coba yang telah dilakukan, telah disimpulkan bahwa kapan pun seseorang menlis sebuah karakter yang sesuai dengan tulisan template di dalam referensi, maka input tulisan tersebut akan selalu dikenal dengan baik.
\end{abstract}

Kata Kunci: Duminant Points.

\section{PENDAHULUAN}

Dengan perkembangan digital tablets dan microcomputers, pengenalan tulisan tangan secara online telah menjadi suatu topik yang sangat terkenal dalam dunia penelitian sejak tahun 1960-an. Satu alasan mengapa topik ini sangat terkenal adalah bahwa pengenalan tulisan tangan secara online menjanjikan kemudahan dalam memasukkan suatu dara ke dalam komputer dengan cara yang lebih dinamis, yaitu dengan cara menggunakan stylus pen bukan hanya sekedar menggunakan keyboard seperti yang kita lakukan selama ini.

Cara kerja pengenalan tulisan tangan secara online berdasarkan mode pengenalan dimana mesin pengenal tulisan dapat mengenali tulisan dari penulis yang ditulis di atas permukaan digitizing tablets dengan menggunakan stylus pen maupun electronic pen. Digitizing tablets tersebut menangkap dynamic information tentang tulisan tangan, seperti bentuk tulisan, sudut dalam tulisan tersebut, kecepatan menulis dan lain-lain di saat tulisan itu dibuat di atas permukaan tablet itu.

Pengenalan tulisan tangan secara offline, dengan menggunakan suatu kontras, terbentuk setelah penulisan telah selesai dan tulisan tersebut langsung ditampilkan ke dalam layar. Setelah itu dynamic information kembali dalam keadaan NULL.

\footnotetext{
* Staf Pengajar Program Studi D3-Manajemen Informatika IKADO

* Staf Pengajar Program Studi S1-Teknik Informatika IKADO
} 
Selain cepat dan lebih alami, keuntungan lain yang dapat dirasakan pada saat menggunakan teknik pengenalan tulisan tangan secara online kemudian diubah melaluli pengenalan tulisan tangan secara offline adalah bahwa terdapat interaksi antara penulis dengan komputer. Penulis langsung dapat membenarkan suatu tulisan di saat pengenalan tulisan tersebut mengalami kesalahan pada saat proses penulisan sedag berlangsung.

Masalah yang dihadapai dalam penelitian ini adalah :

- Bagaimana computer dapat mengenali tulisan tangan suatu karakter dari user.

- Bagaimana metode dominant points lebih cepat dibandingkan dengan metode metode lainnya.

- Bagaimana agar para pengguna PDA atau Pocket pc dengan mudah menginputkan data ke dalam PDA atau Pocket $p c$ dengan menggunakan tulisan tangan.

\section{TINJAUAN PUSTAKA}

\subsection{Landasan Teori}

Pada dasarnya pengenalan tulisan tangan terdiri dari 2 jenis, yaitu secara langsung maupun tidak secara langsung. Pengenalan tulisan tangan di sini berarti bahwa mesin mengenali tulisan selama penulis menulis. Bagian real time atau dynamic digunakan di dalam pengenalan tulisan tangan secara langsung. Selain bergantung dengan teknik pengenalannya dan kecepatan dari komputer yang digunakan, waktu jeda pengenalan juga bergantung dengan tulisan yang ditulis, jelas atau tidak jelas. Di dalam sistem penulisan secara langsung yang dibutuhkan hanyalah kecepatan yang cukup pada saat penulisan.

Pengenalan tulisan secara langsung membutuhkan alat yang dapat menangkap tulisan yang ditulis. Alat yang paling banyak digunakan saat ini adalah tablet elektronik aau digitizer, dimana memiliki spesifikasi resolusi 200 titik per detik, rata-rata pengenalan 100 titik per detik, dihitung dengan cara mengindentifikasikan "tinta" atau pendown.

Metode yang akan diteliti dalam penelitian ini adalah metode Dominant Points, yang merupakan metode terbaru dalam pengenalan tulisan tangan dan juga bisa dikatakan bahwa metode ini adalah pengembangan dari metode sebelumnya, yaitu metode Hidden Markov. Sedangkan metode Dominant Points itu adalah suatu metode dimana komputer melakukan pendekatan dengan melalui beberapa tahapan. Antara lain menggunakan pendekatan dengan perhitungan vektor. Kemudian dilanjutkan dengan menggunakan arah angin. Yang kemudian setelah melalui tahap-tahap tersebut, komputer memiliki suatu kumpulan set referensi dari huruf-huruf dan angak alphanumerik tersebut. Set referensi itulah yang digunakan komputer untuk mengenali tulisan tangan para user. Dan metode Dominant Points ini jauh lebih mudah dan lebih cepat daripada metode Hidden Markov.

\subsection{Hasil Penelitian Sebelumnya}

Keuntungan dari pengenalan tulisan tangan secara langung dengan menggunakan metode titik-titik dominan adalah dapat membentuk suatu informasi temporal atau dynamic dari penulisan. Infornasi ini termasuk jumlah dari pola-pola, bentuk dari pola-pola, dan arah dari penulisan, dan kecepatan dari setiap penulisan. 
Informari temporari dai sistem-sistem penulisan secara langsung memiliki pengenalan yang sangat rumit dengan banyak variasi yang tidak berhubungan dengan suatu citra yang bersifat static. Misalnya, 1 huruf dapat ditulis dengan menggunakan 4 pola tulisan atau dengan variasi bentuk-bentuk pola atau arah, dan banyak variasi yang dapat disamakan ketika proses pengenalan telah selesai. Bagaimanapun juga, semua kerumitan ini dapat ditangani secara sukses, dan informasi temporari dapat digunakan sebagai suatu keuntungan.

Adaptasi adalah keuntungan dari pengenalan tulisan tangan secara langsung dengan menggunakan metode dominant points. Ketika penulis sebelumnya melihat bahwa beberapa dari karakter tulisannya tidak dikenali secara akurat, maka penulis tersebut dapat merubah tulisannya untuk meningkatkan penulisannya. Sehingga penulis langsung bisa beradaptasi dengan sistem pengenalan tersebut. Di sisi lainnya, beberapa pengenalan sangat membantu penulis untuk beradaptasi dengan mudah, biasanya dengan cara memberi contoh bentuk tulisan dari penulis-penulis lainnya untuk pengenalan secara bertahap. Maka dalam situasi seperti ini, terdapat adaptasi antara penulis kepada mesin pengenal (komputer) dan adapatasi antaran mesin pengenal (komputer) kepada penulis.

\subsection{Hipotesis}

Tulisan tangan adalah suatu urutan dari suatu pola, dimana pola tersebut adalah penulisan yang dimulai pada saat pendown dan berakhir pada ssat penup. Karakterdalam penulisan biasanya terbentuk secara berhubungan, satu karakter dapat ditulis secara lengkap sebelum karakter yang beikutnya mulai dtulis, dan karakter tersebut memiliki tipe tertentu dalam suatu bentuk yang harus ditaati. Misalnya adalah menulis dari kiri menuju kanan. Terdapat pengecualian, penulisan untuk cross dan titik di atas huruf itu dapat ditunda. Yang pertama, bentuk utamanya dulu yang ditulis, dan kemudian baru tulisan tersebut lengkap setelah diberi tanda cross dan titik.

Ketajaman sudut antara karakter yang satu dengan karakter yang lainnya sangat sulis dibedakan oleh mein pengenal. Beberapa karakter memiliki ketajaman yang sama, seperti halnya, U-V, C-L, a-d, dan n-h. Ketajaman yang mirip seperti ini juga terjadi antara karakter huruf dan angka, misal 0-O, 1-l, 1-I, Z-2, S-5, G-6. Beberapa dari bentuk tersebut bahkan berpasangan. Mereka hanya dapat dibedakan dalam konteks penggunaannya. Dan juga, banyak huruf besar dan huruf kecil yang juga memiliki ketajaman yang sama. Untuk kebanyakan pasangan ini, faktor yang membedakan adalah ukuran karakter yang relatif untuk spasi baris atau ukuran karakter yang lainnya.

\section{DESAIN PROGRAM}

Masalah dalam pengenalan tulisan tangan secara langsung sangatlah beraneka ragam. Masalah-masalah yang terjadi dalam pengindentifikasian suatu tulisan meliputi set krakter, bentuk penulisan, dan rasio besar-kecilnya tulisan itu sendiri. Secara garis besar, setiap masalah dapat diidentifikasikan dengan berbagai algoritma yang berbedabeda, dimana dalam mengklasifikasikan kesalahan tersebut menggunakan features yang berbeda-beda.

Seluruh karakter alphanumeric dapat ditulisa dengan bentuk yang bermacammacam dengan ketajaman dan posisi yang berbeda-beda. Karakter tulisan secara langsung ditulis dalam digitizing tablet yang dipresentasikan sebagai kelanjutan dari sebuah bentuk, yang terbentuk di saat kursor bergerak, dari posisi pendown ke posisi penup. Penelitian menjelaskan bagaimana pengenalan tulisan tangan secara langsung 
dapat mengenali bentuk tulisan yang berkelanjutan. Sebuah karakter tulisan secara alngsung terbentuk oleh titik dominan yang berkesinambunganyang membentuk suatu tulisan dan hubungan dari arah gerakan tulisan antara titik dominan yang satu dengan titik dominan yang lainnya. Arah gerakan yang menghubungkan titik-titik dominan tersebut digunakan untuk mengpre-klasifikasikan sebuah karakter dan bentuk dari posisinya digunakan untuk mengklasifikasikan karakter tersebut. Baik pre-klasifikasi maupun klasifikasi tersebut didasarkan oleh dynamic programming matching menggunakan ide dari band-Limited Time Warping. Teknik-teknik ini adalah elastic, artinya mereka dapat mengenali bentuk variasi dan berbeda dari biasanya. Kumpulan evolusi bentuk yang direferensikan sudah tersedia.

Rata-rata waktu yang dibutuhkan untuk mengenali sebuah tulisan adalah 0.35 detik per karakter. Pada penelitian ini, terdapat 4 tahapan agar tulisan user dapat dikenali oleh computer. Adapun 4 tahapan secara berurutan yang dapat dilakukan oleh computer dalam pengenalan tulisan tangan ini adalah :

- Data PreProcessing

- Feature Extraction

- Character Classification

- Reference Set Evolution

\subsection{Feature Extraction}

Feature Extraction memiliki beberapa tahapan di dalamnya, yaitu :

- Feature Type.

- Dominant Points.

- Direction Primitive.

- Feature Sequence.

- Other Consideration.

Titik-titik dominant yang dibentuk dengan titik tertentu memiliki beberapa tipe :

a) Pendown and Penup Points.

b) Point yang terbentuk menjadi suatu kurva tertentu.

c) Midpoint antara point-point yang terbentuk dalam titik dominan (a) dan (b).

Sedangkan Direction Primitives adalah satu dari 8 arah mata angina yang terdiri dari 8 arah mata angina : E (East), SE (South East), S (South), SW (South West), W (West), NW (North West), $N$ (North) and NE (North East).

\subsection{Other Consideration}

Terdapat beberapa konsiderasi-konsiderasi special yang lainnya dalam desain sistem ini :

1. Pengenalan dari kumpulan karakter yang berbeda-beda :

Sistem ini dapay mengenali karakter tulisan tangan dari kumpulan karakter yang berbeda-beda, termasuk karakter tulisan bahasa China, karakter tulisan bahasa Inggris, dan karakter tulisan bahsa Arab. Beberapa huruf bahasa Inggris dan tulisan bahasa Arab kelihatan sangat mirip, membuat ini sangat sulit, jika tidak mungkin, mengurangi karakter-karakter yang ambigu tanpa menggunakan context information. 
2. Pengenalan berdasarkan ascenders dan descenders :

Bagaimanapun juga, sejak ascenders dan descenders sangat berguna sekali untuk membedakan antara beberapa huruf-huruf alphabet yang memiliki ketajaman yang sama, garis bantu digunakan untuk mengenali klasifikasi karakter dalam penulisan huruf alphabet. Di dalam sistem ini, tujuan dari ascenders-descenders ini dalam huruf alphabet ini adalah dapat dikenali berdsarkan posisi dari pola yang pertama. Jika bagian atas pola tersebut berada di atas level tengah dari bagian garis atas, maka hururf itu dikenal sebagai huruf ascenders. Di lain sisi, jika bagian bawah pola tersebut berada di bagian bawah dari level tengah dari bagian garis bawah, maka huruf itu dikenal sebagai huruf descenders. Sehingga semua huruf memiliki salah satu sifat tersebut. Tidak satupun huruf yang tidak memiliki sifat tersebut.

3. Menggunakan pseudo extrema dari kurva yang terbentuk :

Pada saat kurva yang terbetnuk menjadi suatu lingkaran tersebut konstan, secara teori tidak ada ekstrem local dari suatu kurva yang dapat dideteksi sepanjang lingkaran. Ini bertujuan agar tidak ada salah pengklasifikasian jika suatu pola tersebut merupakan bagian dari lingkaran atau memiliki sudut yang terlalu halus. Ketika ini terjadi, dapat diidentifikasikan titik tengah dari bagian tersebut sebagai pseudo extrema dari suatu kurva yang terbentuk. Untuk bentuk-bentuk yang lainnya didefinisikan sebagai 2 titik dominan dalam tipe (a) atau (b), dimana dibandingkan anatar keduanya, yaitu panjang dari panah dan rasio dari panjang panah dari total keseluruhan panjang panah tersebut. Jika keduanya menghasilkan hasil yang sama, maka titik tersebut dapat disebut sebagai pseudo extrema dalam suatu kurva yang terbentuk.

\subsection{Character Classification}

Di dalam tahap pengklasifikasian dibagi menjadi 2 tahap. Pertama seleksi kandidat yang terbentuk sebelum tahap preclassification untuk mereduksi jumlah dari klas-klas kandidat yang dibutuhkan untuk dapat diteliti lebih lanjut. Kedua, fine classification yang terbentuk dalam kandidat klas-klas yang telah lolos dalam tahap preclassification untuk dijadikan klasifikasi akhir dari karakter yang telah diinputkan. Kedua tahap tersebut, baik tahap preclassification maupun tahap fine classification membentuk suatu huruf dengna menggunakan dynamic programming.

\subsubsection{Dynamic Programming for Elastic Matching}

Dynamic programming itu sendiri juga memiliki 2 tahap, yaitu :

1. Band-Limited Time Warping

Time Warping adalah teknik yang sangat berguna untuk menemukan hubungan antara 2 string. Dalam bentuk seperti ini, setiap symbol dari setiap karakter dapat dibentuk dari satu atau lebih dari symbol-simbol dalam setiap tulisan, dimana hubungan ini sudah dibentuk sebelumnya.

Setiap hubungan 2 karakter, kemungkinan akan teerdapat banyak time warp. Nilai dari suatu fungsi dapat didefinisikan dengan cara mengevaluasi setiap warpnya. Jika time warping adalah suatu intuisi yang terlihat sebagai hasil dari stretching dari satu karakter untuk mebuat karakter ini lebih tampak sama dari karakter lainnya, kemudian warp yang terbaik memberikan hasil tersebut kepada perbandingan terbaik antara hasil minimum dari suatu stretching karakter dengan hasil maksimum persamaannya antara hubungan 
symbol-simbol antara 2 karakter. Hasil persamaan dan tidak persamaan dapat didefinisikan antara 2 karakter berdasarkan degan warp terbaik.

2. Dynamic Programming Algorithm

Dynamic programming adalah teknik yang sangat berguna sekali untuk menemukan path terpendek dari satu node ke node yang lainnya dalam satu grafik. Ini juga sangat berguna untuk keberhasilan string matching. Di dalam sistem ini, digunakan pendekatan dynamic programming untuk membentuk elastic matching dari suatu urutan.

\subsubsection{Preclassification}

Langkah ini berdasarkan dari penemuan dari nilai maksimum dari band-limited time warping yang mendefinisikan persamaan dari 2 karakter. Sedangkan nilai maksimum itu sendiri ditemukan dengan menggunakan dynamic programming. Metode yang dilakukan aldah menghitung Similary Between Two Sequences.

\subsubsection{Fine Classification}

Langkah Fine Classification adalah dasar dalam menemukan nilai minimum dari band-limited time warping untuk mendefinisikan jarak antara 2 karakter. Nilai minimum itu sendiri dicari dengan menggunakan dynamic programming. Metode yang dilakukan adalah Distance Between Two Sequences.

\subsubsection{Reference Set Evolution}

Secara garis besar, character class mungkin membutuhkan lebih dari satu pola referensi untuk mempresentasikan perbedaan anatra varias-variasi dari suatu tulisan dalam cara penulisan. Sebagai contoh angka “7” dan huruf alphabet “z”. Di samping itu, variasi dalam pola ini dan jumlah dari pola ini munkgin juga dapat ditangani dengan cara yang sama. Bagimanapun juga, kecepatan dan memory juga mempengaruhinya, maka mungkin tidak dapat secara luwes untuk menunjukkan set referensinya untuk dapat diekspand tanpa ada kesalahan. Di tambah pula, class-class tersebut mungkin dapat tidak berguna jika pola-pola referensi tersebut tidak dapat dipilih.

Terdapat 2 proses dalam Reference Set Evolution, yaitu :

1. Intraclass and Interclass Distances

2. Iteractive Evaluation and Deletion

\section{ANALISA DATA}

Setelah melalui berbagai tahapan dalam sistem yang akan dibuat, yaitu data preprocessing, feature extraction, character classification, dan reference set evolution, proses berikutnya adalah suatu hasil percobaan yang telah dilakukan.

1. Character Class

Di dalam sistem ini, akan digunakan 62 character classes dengan perbedaan dalam cara penulisannya dalam penelitian ini, angka 0-9, huruf besar A-Z, dan huruf kecil a-z.

2. Data Collection and Reference Set

- Data Collection

Dalam setiap evaluasi dari performa di dalam sistem ini, terdapat beberapa mahasiswa yang berpartisipasi untuk memeberikan kontribusi data tulisan tangannya untuk percobaan pengenalan tulisan tangan ini. 
Setiap data disimpan dalam 3 file berbeda, angka, huruf besar, dan huruf kecil.

Dalam setiap penulisannya untuk data yang pertama, setiap sukarelawan diminta untuk menuliskan angka 0-9 sebanyak 2 kali dengan menggunakan cara penulisan yang berbeda. Untuk data yang kedua, setiap sukarelawan diminta untuk menuliskan huruf besar A-Z dengan menggunakan bentuk tertentu, dan kemudian menulis sesuai dengan gaya tulisannya masing-masing. Kemudian untuk data ketiga, setiap sukarelawan diminta untuk menulis huruf kecil a-z sebanyak 2 kali dalam 2 perbedaan cara penulisan.

- Secara keseluruhan terdapat 124 karakter yang telah ditulis oleh setiap sukarelawan. Dan seluruh karakter tersebut digunakan sebagai pola referensi dari inisial set referensi. Set ini secara keseluruhan memiliki beberapa variasi dengan ketentuan jumlah pola dan bentuk pola.

Evolusi dari set referensi telah terbentuk dengan menggunakan data dari para sikarelwan secara random. Maksimal dari 4 pola referensi digunakan untuk setiap character class. Bagaimanapun juga, 2 inisial pola referensi untuk setiap class telah terbentuk sebagai "pasti" dan tidak pernah terhapus. Setelah prosedur ini dijalankan, 56 pola referensi baru telah terpilih dari seluruh total 180 pola dalam set referensi. Set referensi ini kemudian digunakan dalam pengenalan dari karakter yang ditulis oleh 5 sukarelawan.

\section{Recogniton Result}

Dengan menggunakan pendekatan secara elastis, sistem ini dapat mentoleransi variasi local dan bentuk tak terduga, seperti garis yang berlebih dan bentuk yang "aneh”. Dalam uji coba, telah ditemukan bahwa ketika seseorang menulis sebuah karakter yang sesuai dengan yang ada dalam set referensi tersebut, maka karakter tersebut akan selalu dikenali dengan baik.

\section{KESIMPULAN DAN SARAN}

\subsection{Kesimpulan}

Dengan menggunakan pendekatan elastic matching, sistem ini dapat mentoleransi variasi local dan bentuk yang rusak seperti pola yang melebar dan garis yang keluar dari bentuknya. Dalam uji coba, telah disimpulkan bahwa kapan pun seseorang menulis sebuah karakter yang sesuai dengan tulisan template di dalam set referensi, maka input tulisan tersebut akan selalu dikenal dengan baik.

Hasil pengenalan tulisan tangan ini berdasarkan data dari 15 orang yang hasilnya telah diketahui. Rata-rata pengenalan untuk angka adalah sangat tinggi, sedangkan untuk huruf kecil tidak lebih rendah. Secara keseluruhan, pengenalan ini memiliki ratarata $91,0 \%$ dengan 7,9\% rata-rata pergantian dan 1,1\% rata-rata penolakan.

Maka dari hasil penelitian dapat disimpulkan bahwa :

1. Metode Dominant Points memiliki akurasi yang tinggi, sehingga kesalahan jarang terjadi dalam pengenalan tulisan tangan suatu karakter yang diinputkan user.

2. Metode Dominant Points sangat baik memiliki tingkat ketelitian yang paling tinggi ketika mengenali suatu karakter huruf besar. 
3. Metode Dominant Points dalam mengenali suatu karakter lebih cepat dibandingkan dengan menggunakan metode lainnya, karena metode ini menggunakan metode dynamic programming algorithm yang tidak digunakan oleh metode lainnya.

\subsection{Saran}

Pada dasarnya, pengenalan tulisan tangan ini mempunyai prinsip yang sama dengan Backpropagation pada "Kecerdasan Buatan”. Oleh karena itu, untuk memahami dan mendalami pengenalan tulisan tangan ini, ada baiknya kita mempelajari hal-hal dasar "Kecerdasan Buatan" mengenail "Pengenalan Pola” terlebih dahulu sebelum mempelajari pengenalan tulisan tangan. Karena pengenalan tulisan tangan ini merupakan kelanjutan dari pengenalan pola.

\section{DAFTAR PUSTAKA}

Tappert C.C, Y. Suen Ching, Wakahara T., The State of the Art in On-Line Handwriting Recognition, August 1990

Li, X., Yeung D.Y., On-Line handwritten Alphanumeric Character Recoginition Using Dominant Points in Strokes, Hongkong University of Science and Technology, Department of Computer Science, August 23, 1996.

Leung, H. W. H., Reprensations, Feature Extraction, Matching and Relevancce Feedback For Sketch Retreal, Carnegie Mellon University, Electrical and Computer Engineering, June 2003. 